\title{
Blood cells and serum chemistry in the world's largest fish: the whale shark Rhincodon typus
}

\author{
Alistair D. M. Dove ${ }^{1, *}$, Jill Arnold ${ }^{2}$, Tonya M. Clauss ${ }^{1}$ \\ ${ }^{1}$ Veterinary Services and Conservation Medicine, Georgia Aquarium, 225 Baker Street, Atlanta, Georgia 30313, USA \\ ${ }^{2}$ National Aquarium in Baltimore, 501 E. Pratt Street, Baltimore, Maryland 21202, USA
}

\begin{abstract}
Descriptive information regarding the peripheral blood of normal whale sharks Rhincodon typus Smith 1828 is presented based on samples collected from 2 healthy female specimens held in an aquarium collection. Erythrocyte morphology was similar to other orectolobiforms and major leukocyte types were similar to other non-carcharhinid sharks. The numerically dominant population was the lymphocyte $(46 \%)$, followed by the fine eosinophilic granulocyte or heterophil $(39.5 \%)$. The remaining $15 \%$ of white blood cells were divided among coarse eosinophilic granulocytes or eosinophils, simple neutrophils, monocytes similar to those of most elasmobranchs and a rare basophilic stippled granulocyte or basophil. Thrombocytes were similar to those of other shark species; no granulated thrombocytes were observed in this species. Blood gas data and serum chemistry values are also presented. For comparison, 22 blood samples collected from 2 moribund male specimens showed that the heterophil/lymphocyte ratio may be a potentially useful biomarker of whale shark health. A pattern of marked heterophilia in these animals became more pronounced as their clinical condition deteriorated. These data represent the first exploration of the internal biology of the world's largest fish.
\end{abstract}

KEY WORDS: Rhincodon $\cdot$ Whale shark $\cdot$ Blood $\cdot$ Serum chemistry

\section{INTRODUCTION}

Whale sharks are circum-tropical and -subtropical planktivorous sharks that grow to lengths of up to $20 \mathrm{~m}$ and weights in excess of $30000 \mathrm{~kg}$ (Chen et al. 1999), making them not only the largest elasmobranch but the largest fish of any kind. Despite their enormous size and global distribution, the biology of whale sharks remains largely unknown (Colman 1997, Stevens 2007). Most studies to date have focused on population estimates or characterization in geographically restricted areas. More recent research has attempted to explore the feeding biology, population dynamics and migratory behaviour (Graham et al. 2006, Graham \& Roberts 2007, Martin 2007, Rowat et al. 2007). No studies have been published on health and homeostasis in this species.

Blood is the fundamental body fluid and the composition of both its cellular and humoral components is informative in evaluating the health of animals. Elasmo- branchs are no exception; a growing number of studies have explored health and homeostasis of sharks and rays based on blood cells (e.g. Arnold 2005, Old \& Huveneers 2006) and serum or plasma analytes (e.g. Seibel \& Walsh 2002, Anderson et al. 2007, De Boeck et al. 2007). However, there are no published reports describing blood collection from wild or captive specimens of whale sharks prior to the present study and, consequently, no studies have explored haematology or blood chemistry in this species.

The maintenance of several whale sharks in a large (24 million 1) exhibit system at the Georgia Aquarium has provided an opportunity to redress the dearth of information about the basic biology of this species. The present study provides preliminary data concerning the haematology and clinical chemistry of this unique elasmobranch, with a view to improved husbandry practices and understanding of homeostasis in the world's largest fish. 


\section{MATERIALS AND METHODS}

Blood collection. Blood was obtained from 2 healthy, subadult female whale sharks approximately $7 \mathrm{~m}$ in length, both of which were sampled on 2 occasions. The animals were corralled for physical examinations by using SCUBA divers to guide them into a vinyl stretcher suspended directly in the exhibit aquarium. The stretcher was then raised slightly using a motorized gantry, such that the animal was constrained by the stretcher but the gills of the shark were never out of the water. During restraint, which lasted 20 to $40 \mathrm{~min}$, water was pumped directly into the mouth cavity via a soft silicone bit piece, using exhibit water supplied by a jacuzzi pump. This water was supplemented with compressed medical oxygen via a venturi injector, such that levels in the water within the stretcher remained at approximately 110 to $125 \%$ saturation; this slightly elevated oxygen level has a sedative effect.

On both occasions, blood was drawn from 2 sites on the body of each shark: the dorsal posterior cardinal vein, with associated sinus (a superficial vessel at the posterior aspect of the base of the second dorsal fin, see Rasmussen \& Murru 1992), and the caudal vein/artery via the ventral pre-caudal pit. Venipuncture instruments differed between occasions, but in general a 1 inch, 18 gauge needle was used for the dorsal postcardinal vein and a 3.5 inch, 18 gauge needle was used for the caudal vein. In all cases, needles were connected to a $20 \mathrm{ml}$ syringe with a 6 or 15 inch extension set.

Due to the substantial logistic challenge of sample collection on such large animals and the absence of reliable, tested field restraint methods, it was not possible to gather robust population averages for haematology or blood chemistry values, nor lengthy longitudinal series of samples from the same healthy individuals. We are not able, therefore, to present true reference ranges for haematological parameters in healthy whale sharks. Rather, these numbers gleaned from captive animals should be interpreted as a guide of what might be expected in this species.

Longitudinal series of samples were collected from 2 male whale sharks that stopped eating in September 2006. These animals had $\mathrm{n}=6$ and $\mathrm{n}=16$ samples taken, and died in January and June of 2007, respectively. Samples from the abnormal males were collected using the same methods applied to the healthy females.

Haematology. Initially, differential smears were made using blood collected with dry EDTA anticoagulant or without anticoagulant. After some experimentation with EDTA, heparin and other anticoagulants, buffered $3.8 \%$ sodium citrate proved to be a more effective anticoagulant that produced more consistent smears with fewer erythrocyte artifacts and fewer microclots. While this anticoagulant was liquid and could therefore slightly dilute white blood cell (WBC) counts made using a haemacytometer, the volume of diluent was insignificant and it produced better results with fewer micro-clots than other anticoagulants, so it was used for the differential images and measurements presented herein. Commercial buffered sodium citrate anticoagulant has a lower osmolality than shark blood, but no cell lysis was observed as a result of this, probably because the tiny volume of anticoagulant was overwhelmed by the larger volume of more concentrated blood. Blood smears were made using standard slide-draw methods. Smears were stained using the Protocol ${ }^{\circledR}$ rapid staining method, which stains nuclei purple and typical cytoplasm a pale pink.

Measurements included haematocrit by centrifugation (packed cell volume), plasma protein concentration by refractometer and total WBC count. The WBC count was determined using a modified version of the Natt-Herrick method, wherein the stock solution was supplemented with $0.1 \mathrm{~g}$ sodium chloride and $0.3 \mathrm{~g}$ urea per $10 \mathrm{ml}$, to match the osmolality of elasmobranch blood (Arnold, 2005). Sodium citrate whole blood was diluted 1:100 with the modified NattHerrick solution, and mixed for a minimum of $20 \mathrm{~min}$ to allow uptake of the stain by the WBCs. This mixture was then loaded into in an improved Neubauer haemacytometer and all cells counted.

Clinical chemistry. Data on blood gas concentrations and acid-base balance were gathered immediately after blood draw using whole blood without anticoagulants on a Heska iStat analyzer (Heska), using the CG4+ and/or CG8+ cartridges. Between them, these 2 cartridges measure $\mathrm{TCO}_{2}, \mathrm{pCO}_{2}, \mathrm{pO}_{2}, \mathrm{sO}_{2}, \mathrm{pH}$, lactate, glucose, $\mathrm{HCO}_{3}$, base excess, $\mathrm{Na}, \mathrm{K}$ and ionized $\mathrm{Ca}$. Serum electrolytes were measured using an Idexx VetLyte electrolyte analyzer (Idexx Laboratories) after 1:2 dilution in distilled water to reduce the sodium and chloride concentrations into the reading range of the instrument. Clinical chemistry parameters were obtained from serum using an Abaxis VetScan2 clinical chemistry analyzer using the Comprehensive Diagnostic Profile and Avian-Reptilian Profile Plus, according to the manufacturer's instructions (Abaxis). Clinical chemistry values are based on 4 samples from one female and 3 samples from the other female shark.

\section{RESULTS}

\section{Haematology}

A total of 8 cell types were observed in the mixed venous/arterial blood we collected (in order of decreasing proportion): erythrocyte, thrombocyte, lymphocyte, heterophil (fine eosinophilic granulocyte), 
Table 1. Rhincodon typus. Morphometrics of whale shark blood cells based on samples from caudal vessels in 2 healthy females. All measurements are in $\mu \mathrm{m}$. na: not applicable

\begin{tabular}{|c|c|c|c|c|c|}
\hline $\begin{array}{l}\text { Cell type } \\
\text { (no. counted) }\end{array}$ & $\begin{array}{l}\text { Cell } \\
\text { length }\end{array}$ & $\begin{array}{c}\text { Cell } \\
\text { width }\end{array}$ & $\begin{array}{l}\text { Nucleus } \\
\text { length }\end{array}$ & $\begin{array}{l}\text { Nucleus } \\
\text { width }\end{array}$ & $\begin{array}{c}\text { Granule } \\
\text { length, width }\end{array}$ \\
\hline Erythrocyte (20) & & & & & na \\
\hline Mean & 21.99 & 14.28 & 7.96 & 6.21 & \\
\hline $\mathrm{SD}$ & 1.34 & 0.75 & 0.47 & 0.32 & \\
\hline Min & 20.06 & 13.24 & 7.06 & 5.66 & \\
\hline Max & 24.98 & 15.80 & 8.79 & 6.72 & \\
\hline Monocyte (12) & & & & & na \\
\hline Mean & 17.04 & 15.06 & 10.35 & 12.02 & \\
\hline SD & 1.44 & 1.29 & 0.96 & 1.17 & \\
\hline Min & 13.85 & 13.08 & 8.26 & 10.67 & \\
\hline Max & 19.62 & 17.47 & 11.26 & 13.99 & \\
\hline Neutrophil (5) & & & & & Indistinct \\
\hline Mean & 21.93 & 18.93 & 9.82 & 9.63 & \\
\hline $\mathrm{SD}$ & 2.00 & 0.86 & 1.76 & 1.50 & \\
\hline Min & 19.54 & 18.06 & 7.79 & 8.05 & \\
\hline Max & 24.44 & 19.80 & 12.10 & 11.41 & \\
\hline Heterophil (13) & & & & & Indistinct \\
\hline Mean & 16.90 & 16.65 & 8.33 & 10.13 & \\
\hline $\mathrm{SD}$ & 1.25 & 01.06 & 0.88 & 1.19 & \\
\hline Min & 14.71 & 14.36 & 6.90 & 7.30 & \\
\hline Max & 18.92 & 18.43 & 10.05 & 12.63 & \\
\hline \multicolumn{6}{|l|}{ Eosinophil (12) } \\
\hline Mean & 19.14 & 19.58 & 7.84 & 10.42 & $2.27,1.12$ \\
\hline $\mathrm{SD}$ & 0.92 & 1.56 & 01.03 & 1.30 & $0.17,0.07$ \\
\hline Min & 17.64 & 17.34 & 6.72 & 8.19 & $2.04,1.04$ \\
\hline Max & 20.55 & 22.17 & 10.39 & 12.52 & $2.61,1.23$ \\
\hline Basophil (5) & & & & & Indistinct \\
\hline Mean & 16.26 & 15.90 & 8.01 & 9.56 & \\
\hline $\mathrm{SD}$ & 0.52 & 0.85 & 1.26 & 1.40 & \\
\hline Min & 15.88 & 15.17 & 6.73 & 7.96 & \\
\hline $\operatorname{Max}$ & 17.11 & 17.24 & 10.03 & 11.73 & \\
\hline Lymphocyte (12) & & & & & na \\
\hline Mean & 15.72 & 9.33 & 10.88 & 7.99 & \\
\hline SD & 3.07 & 1.87 & 1.52 & 1.09 & \\
\hline Min & 10.02 & 7.64 & 7.97 & 6.51 & \\
\hline Max & 20.64 & 14.00 & 12.98 & 10.99 & \\
\hline Thrombocyte (20) & & & & & na \\
\hline Mean & 17.39 & 7.32 & 11.59 & 5.99 & \\
\hline $\mathrm{SD}$ & 1.11 & 0.54 & 0.81 & 0.66 & \\
\hline Min & 15.74 & 6.32 & 10.42 & 4.84 & \\
\hline $\operatorname{Max}$ & 19.86 & 8.26 & 13.27 & 6.95 & \\
\hline
\end{tabular}

The most common WBC in healthy whale sharks was the lymphocyte. These were roughly similar to those of other fishes in being a small cell with a very high nucleus/cytoplasm ratio and distinctly basophilic cytoplasm. As with many animals, the lymphocytes of Rhincodon typus were quite variable, appearing most often as a small spherical cell with a densely basophilic nucleus and a crescent of bluish cytoplasm at one pole, but also as both a larger cell with more cytoplasm, similar to the mammalian plasma cell, and as a more active-looking cell with distinct surface blebs.

The next most abundant cell resembles the heterophil of Campbell \& Ellis (2007); this cell is equivalent to the fine eosinophilic granulocyte of Arnold (2005). Heterophils were of similar overall size to erythrocytes, but round rather than elliptical. The cytoplasm varied from neutral to distinctly basophilic and was replete with indistinct, irregular, slightly eosinophilic granules. The nucleus varied clinally from spherical to deeply segmented. Ostensibly similar, the eosinophil or coarse eosinophilic granulocyte (Arnold 2005) was the next most common cell and differed from the heterophil in having large and distinct cigar-shaped granules that were prominently and vividly eosinophilic.

The remaining 3 cell types made up less than $10 \%$ of WBCs. The monocytes were similar to those of other elasmobranchs, appearing as larger cells with abundant frothy cytoplasm and an oblong nucleus, eosinophil (coarse eosinophilic granulocyte), monocyte, neutrophil and basophil (basophilic stippled granulocyte). Morphometric characteristics of these cells are presented in Table 1 and illustrated in Fig. 1. Normal haematological parameters of Rhincodon typus are summarised in Table 2.

Erythrocytes were typical of elasmobranchs (Fig. 1); cells were oval with a central oval to slightly elongated nucleus. A small amount of anisocytosis and anisokaryosis was observed, as is typical for many lower vertebrates. Young erythrocytes were also observed regularly; these were rounder, more basophilic cells with larger rounder nuclei containing apparently lesscondensed chromatin. often with an indentation on the inner aspect, lending it a kidney bean appearance. The basophil or basophilic stippled granulocyte was uncommon but quite distinctive. This cell had neutral cytoplasm and sparse, irregular, but distinctly basophilic granules. The neutrophil was the least common cell type; these were large, distinctly round cells with a compact nucleus and abundant neutral to slightly eosinophilic cytoplasm that was largely devoid of granular material; those granules that were present appeared neutral to slightly basophilic.

The thrombocytes were similar to those of other elasmobranchs and fishes. No granulated thrombocytes were observed. 


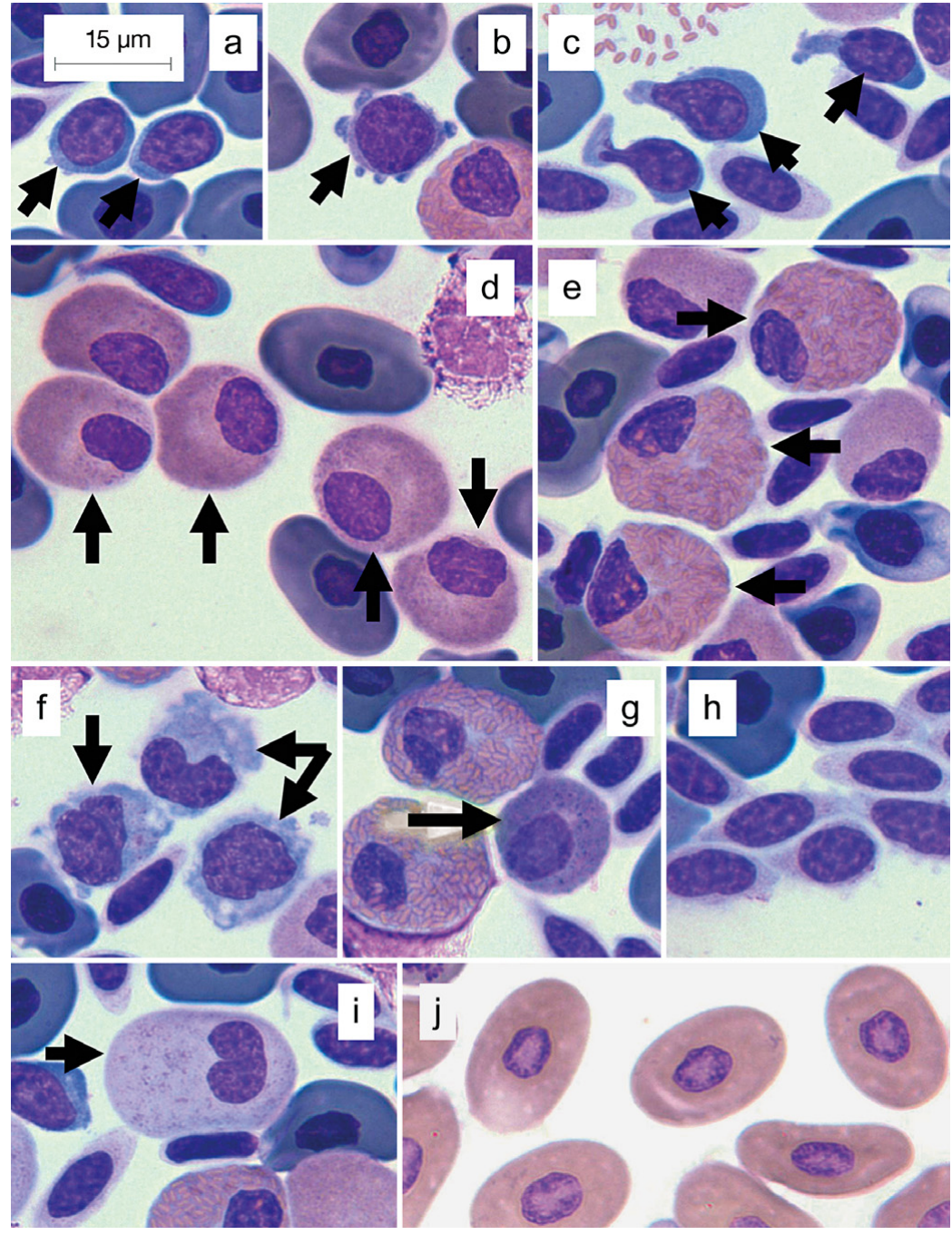

Fig. 1. Rhincodon typus. Differential haematology of blood from the caudal vessels of the whale shark. (a-c) lymphocytes (arrows); (d) heterophils (arrows); (e) eosinophils (arrows); (f) monocytes (arrows); (g) basophil (arrow); (h) thrombocytes; (i) neutrophil (arrow); (j) erythrocytes. All photographs to same scale as (a)

\section{Clinical chemistry}

The results of clinical chemistry analyses are summarised in Table 3.

\section{Abnormal values}

Results above refer to healthy female whale sharks. We also analysed 2 time series of samples from 2 male whale sharks that were inappetant for 6 and 9 mo before dying in January and June of 2007, respectively. Both animals displayed an elevated WBC count throughout their progression (Fig. 2), and the ratio of heterophils to lymphocytes varied in a manner consistent with observed changes in overall health (Fig. 3). Fig. 4 shows that this variation stemmed from increases in the absolute numbers of heterophils more so (but not entirely) than from decreases in the number of circulating lymphocytes.

\section{Effects of venipuncture site}

Table 4 presents a comparison of haematological and clinical chemistry data from different venipuncture sites on the whale shark. Haematocrit differed by half between the 2 sites and there were also differences in plasma protein, total WBC count and lactate concentration.

\section{DISCUSSION}

Table 2. Rhincodon typus. Average haematological values from caudal vessel blood in 2 healthy female whale sharks ( $\mathrm{n}=2$ samples per shark). Haematocrit (packed cell volume): $21 \%$

\begin{tabular}{|lcc|}
\hline Parameter & $\begin{array}{c}\text { Relative } \\
(\%)\end{array}$ & $\begin{array}{c}\text { Absolute } \\
\left(\text { cells ml }^{-1}\right)\end{array}$ \\
\hline White blood cells & - & 5090 \\
Lymphocyte & 46.0 & 2369 \\
Heterophil & 39.5 & 2009 \\
Eosinophil & 6.5 & 331 \\
Monocyte & 6.3 & 321 \\
Basophil & 1.8 & 90 \\
Neutrophil & 0.9 & 45 \\
\hline
\end{tabular}

The present study presents for the first time information on the internal biology of the world's largest fish. In general, the values observed for haematology and blood chemistry in the 2 healthy female animals were similar to those of other elasmobranchs, with some notable exceptions. Creatine kinase, for example, is often very high in elasmobranchs relative to mammals, but was quite low in Rhincodon typus (see Table 3).

Haemocyte morphology of whale sharks was approximately similar to that of other orectolobiform sharks we have examined, such as wobbegongs Orectolobus spp., and also similar to published descriptions of wobbegong blood (Old \& Huveneers 2006), but somewhat dif- 
Table 3. Rhincodon typus. Average blood chemistry and blood gas values ( 4 and 3 readings, respectively) from 2 female whale sharks, taken from the caudal vessel (mean $\pm \mathrm{SD}$; $\mathrm{n}=7$ ). nd: not detected

\begin{tabular}{|c|c|}
\hline Analyte & Average concentration \\
\hline Alkaline phosphatase & $20.5 \pm 5.3 \mathrm{mg} \mathrm{dl}^{-1}$ \\
\hline Alanine aminotransferase & $9.0 \pm 3.7 \mathrm{mg} \mathrm{dl}^{-1}$ \\
\hline Aspartate aminotransferase & $13.6 \pm 5.0 \mathrm{mg} \mathrm{dl}^{-1}$ \\
\hline Creatine kinase & $88.1 \pm 53.3 \mathrm{mg} \mathrm{dl}^{-1}$ \\
\hline Albumin & nd \\
\hline Amylase & nd \\
\hline Uric acid & $0.9 \pm 0.1 \mathrm{mg} \mathrm{dl}^{-1}$ \\
\hline Total bilirubin & $0.22 \pm 0.08 \mathrm{mg} \mathrm{dl}^{-1}$ \\
\hline Calcium & $13.6 \pm 0.4 \mathrm{mg} \mathrm{dl}^{-1}$ \\
\hline Ionized calcium & $2.25 \pm 0.21 \mathrm{mg} \mathrm{dl}^{-1}$ \\
\hline Phosphorus & $4.1 \pm 0.3 \mathrm{mg} \mathrm{dl}^{-1}$ \\
\hline Creatinine & $0.35 \pm 0.07 \mathrm{mg} \mathrm{dl}^{-1}$ \\
\hline Glucose & $64.0 \pm 3.6 \mathrm{mg} \mathrm{dl}^{-1}$ \\
\hline Sodium & $284.0 \pm 19.5 \mathrm{mEq} \mathrm{l}^{-1}$ \\
\hline Potassium & $5.54 \pm 0.36 \mathrm{mEq} \mathrm{l}^{-1}$ \\
\hline Chloride & $257.9 \pm 19.9 \mathrm{mEq} \mathrm{l}^{-1}$ \\
\hline Total protein & $2.4 \pm 0.3 \mathrm{mg} \mathrm{dl}^{-1}$ \\
\hline $\mathrm{pCO}_{2}$ & $7.2 \pm 2.6 \mathrm{~mm} \mathrm{Hg}$ \\
\hline $\mathrm{TCO}_{2}$ & $<5.0 \mathrm{mmol} \mathrm{l}^{-1}$ \\
\hline $\mathrm{pO}_{2}$ & $36.2 \pm 21.9 \mathrm{~mm} \mathrm{Hg}$ \\
\hline $\mathrm{sO}_{2}$ & $71.7 \pm 31.3 \%$ saturation \\
\hline $\mathrm{pH}$ & $7.37 \pm 0.22$ \\
\hline Lactate & $2.35 \pm 1.32 \mathrm{mmol} \mathrm{l}^{-1}$ \\
\hline $\mathrm{HCO}_{3}$ & $3.7 \pm 0.6 \mathrm{mmol} \mathrm{l}^{-1}$ \\
\hline Base excess & $-23.2 \pm 1.2 \mathrm{mmol} \mathrm{l}^{-1}$ \\
\hline
\end{tabular}

ferent from carcharhinid sharks (Arnold 2005). Orectolobiform species have erythrocytes that are much larger than those of most fishes and slightly larger than those of carcharhinid sharks. At $22 \mu \mathrm{m}$ in length, the erythrocytes of Rhincodon typus are large, but they are not as large as those of many amphibians and certainly do not approach the largest erythrocytes known, those of Amphiuma spp. ( 65 $\mu \mathrm{m})$ (Hartman \& Lessler 1964, Snyder \& Sheafor 1999). WBC counts were approximately half of what we have observed for other orectolobiforms (authors' unpubl. data), and at the low end of what we have seen for all elasmobranchs, where values well in excess of $30000 \mathrm{ml}^{-1}$ are not unusual.

The WBC differential of whale sharks is essentially similar to that of other elasmobranchs (Walsh \& Luer 2004, Campbell \& Ellis 2007). The 2 most prominent cells, the lymphocyte and heterophil, are both found in other species and occur in whale sharks in similar proportions. Whale sharks are somewhat unusual relative to some other lower vertebrates in that they possess both heterophils and neutrophils, but this is far from a rigid rule. Granulated thrombocytes were not observed in whale shark blood smears, whereas these cells have been described in the carcharhinid sandbar shark Carcharhinus plumbeus (Arnold 2005) and we have observed them in several other elasmobranch species, including several sting ray species (authors' unpubl. data). Stokes \& Firkin (1971) have observed phagocytic activity in elasmobranch thrombocytes, but Pica et al. (1990) suggested a function similar to that of platelets in mammals, based on the presence of platelet factors and a surface canalicular system. Thrombocyte microclots were seen in some smears made using EDTA anticoagulant, so we are inclined to agree with Pica et al. (1990), though an additional phagocytic role cannot be excluded. Thrombocytes were not seen to take up NattHerrick stain in the present study and so were not included in the WBC count or the differential.

The serum chemistry of whale sharks provided interesting contrast with that of other elasmobranchs. The creatine kinase level was substantially lower than we have seen with other species, where normal resting values in excess of $1200 \mathrm{mg} \mathrm{dl}^{-1}$ are not uncommon (A. Dove pers. obs.). We did not detect albumins in whale shark blood using VetScan rotors, and we have not detected albumins in any other elasmobranch species we have examined ( $\mathrm{n}=11$ species); this observation is consistent with the findings of Metcalf \& Gemmell (2005).

Perhaps the most interesting contrast was that between the 2 venipuncture sites: caudal vessels and second dorsal fin sinus (Table 4). There was a pronounced difference in several parameters, both haematological and chemical. Haematocrit is typically less than half the value at the second dorsal sinus when compared to

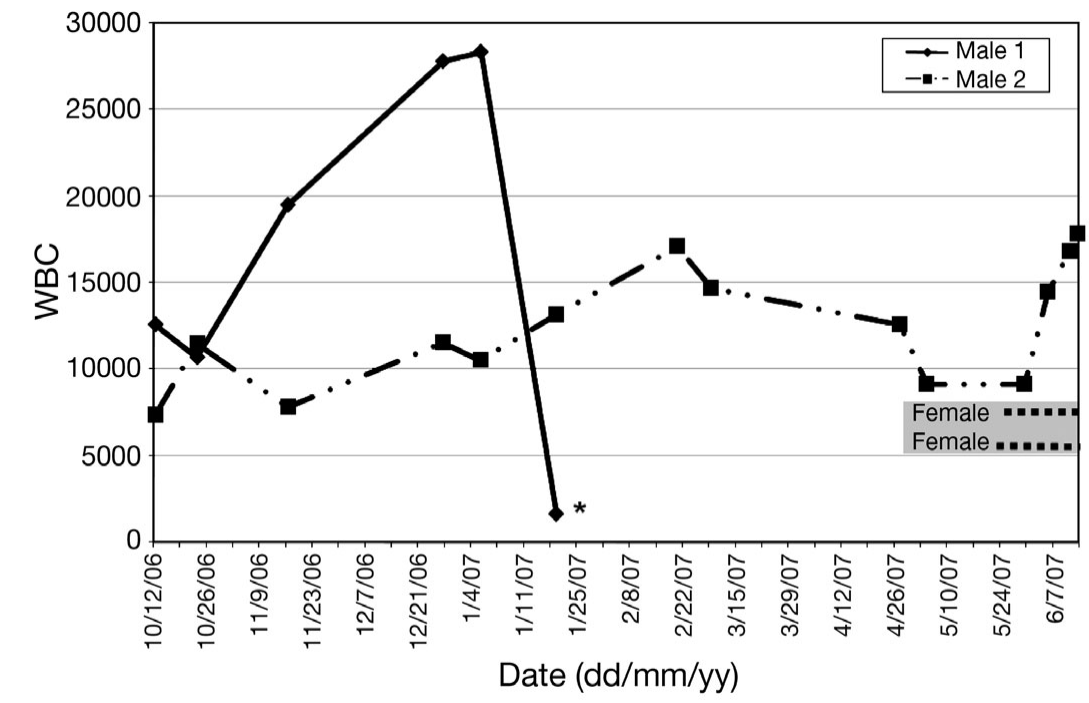

Fig. 2. Rhincodon typus. Changes in white blood cell (WBC) count during clinical progression towards death in 2 male whale sharks (Male $1 \& 2$ ). The shaded area shows average values for 2 healthy females (Female $1 \& 2$ ). ${ }^{*}$ peri-mortem sample 


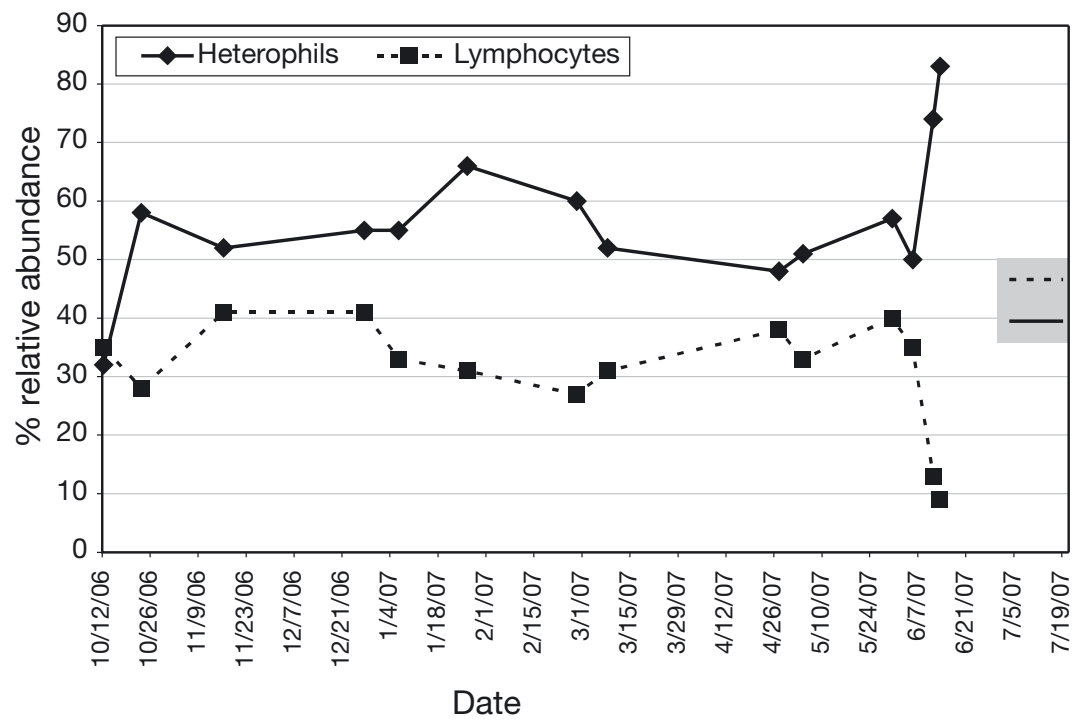

Fig. 3. Rhincodon typus. Changes in relative abundance of heterophils and lymphocytes during the clinical progression of an inappetant male whale shark (Male 1) that died in June 2007. The shaded area shows normal relative proportions of heterophils (solid line) and lymphocytes (dashed line) established from 2 healthy females; these are reversed in the abnormal animal

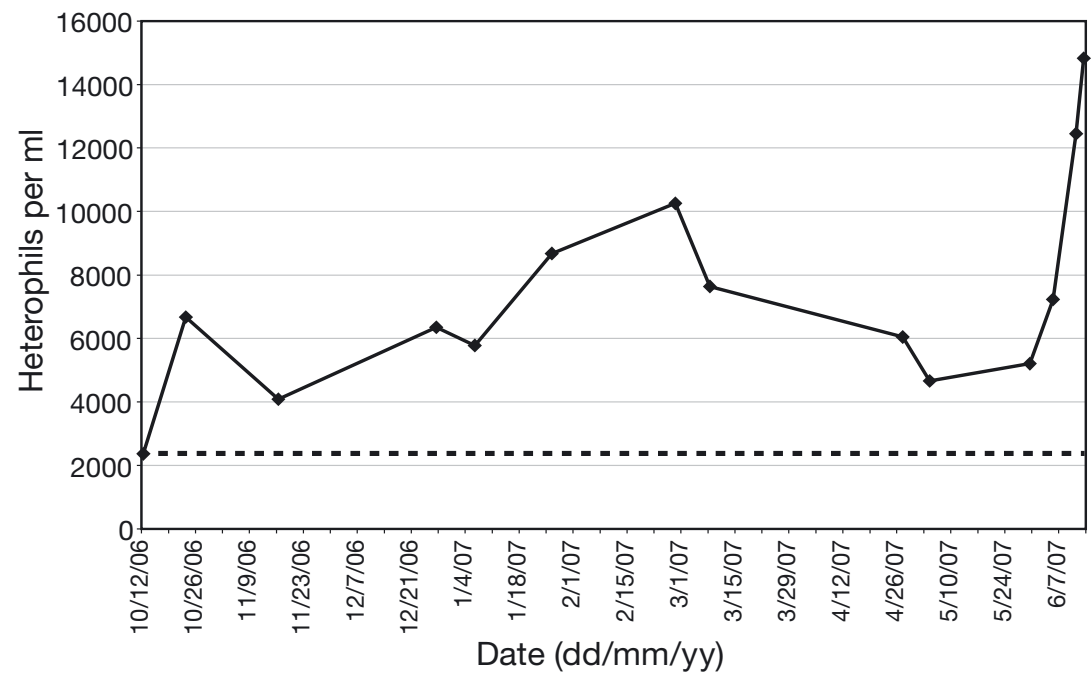

Fig. 4. Rhincodon typus. Changes in absolute abundance of heterophils during the clinical progression of an inappetant male whale shark (Male 2) that died in June 2007, showing that the pattern depicted in Fig. 2 is largely due to changes in the abundance of heterophils. Horizontal dashed line shows the mean absolute heterophil count from two healthy females

Table 4. Rhincodon typus. Differences between caudal vein and dorsal posterior cardinal vein and associated sinus haematology and clinical chemistry values in 2 healthy female whale sharks. Values derived from 4 total readings, 2 per animal

\begin{tabular}{|c|c|c|c|}
\hline Parameter & $\begin{array}{l}\text { Ventral midline } \\
\text { average }\end{array}$ & $\begin{array}{c}\text { 2nd dorsal } \\
\text { sinus average }\end{array}$ & Difference \\
\hline Haematocrit (\%) & 21 & 9.5 & -11.5 \\
\hline White blood cells (no. $\mathrm{ml}^{-1}$ ) & 5087 & 3231 & -1856 \\
\hline Plasma protein $\left(\mathrm{mg} \mathrm{dl}^{-1}\right)$ & 4.55 & 3.15 & -1.4 \\
\hline Lactate $\left(\mathrm{mmol} \mathrm{l}^{-1}\right)$ & 3.16 & 0.33 & -2.84 \\
\hline
\end{tabular}

the caudal vessels. Lactate concentrations at the second dorsal sinus were a tenth of the concentration recovered from the caudal vessels. This result may have been affected by the sequence in which the 2 sites were sampled, such that lactate had time to accumulate in the blood before the caudal vessel was sampled. Glucose values were similar between the samples, however, which provides no evidence of a stress hyperglycaemic response and tends to counteract the notion that differences in lactate relate to cumulative physiological stress from the exam.

The marked differences in haematological and chemical values from the second dorsal sinus suggest that this site yields a mixed fluid rather than a homogenous blood sample. While the secondary circulatory system of whale sharks has not been described, it is clear that elasmobranchs do possess a lymphatic system, so it seems most likely that the second dorsal sinus is part of that system. This should be considered when sampling whale shark blood from this site.

The comparison of values from the 2 healthy females against 2 terminally inappetant males revealed that the males developed a leukocytosis with marked absolute heterophilia as their health deteriorated (see Figs. 2 \& 3). The heterophil/lymphocyte ratio may therefore be a useful index of health in whale sharks. The female whale sharks both had positive ratios wherein lymphocyte numbers exceeded heterophils in both proportion and absolute number; we have since established that this pattern holds for healthy males as well. The inppetant males both had negative ratios throughout their progression, frequently with 2 or more heterophils for every lymphocyte and progressing to profoundly negative ratios of -10 to -12 just prior to death. A similar reversal pattern in birds (see Gross \& Seigel 1983) has led to the use of the heterophil/ lymphocyte ratio as a stress indicator. Unfortunately, our result is confounded by the differing gender of the healthy and unhealthy animals, but the pattern seems worth further investigation. 
The present study has made preliminary inroads into the exploration of the internal biology of the whale shark, but there is a tremendous amount that is still not understood about this and many other elasmobranch species. Future studies should focus on confirming the functional roles of different cell types and understanding the significance of different chemical or enzymatic indices in plasma and/or serum. Research should also seek out novel analytes that may be unique to, or especially useful for, elasmobranchs. Armed with this knowledge, we will be better able to identify good biomarkers of health in the blood of captive sharks and rays, which will improve elasmobranch husbandry and medicine and also improve our capacity to understand, monitor and explore elasmobranch health in natural settings.

Acknowledgements. The authors appreciate the input of the anonymous reviewers and the many husbandry and veterinary staff at Georgia Aquarium who made possible the collection of blood samples from whale sharks. A.D. appreciates discussions and guidance from B. Carlson, T. Mullican and G. Bossart. This work was funded by the Correll Center for Aquatic Animal Health at Georgia Aquarium.

\section{LITERATURE CITED}

Anderson WG, Taylor JR, Good JP, Hazon N, Grosell M (2007) Body fluid volume regulation in elasmobranch fish. Comp Biochem Physiol A 148:3-13

Arnold JE (2005) Hematology of the sandbar shark, Carcharhinus plumbeus: standardization of complete blood count techniques for elasmobranchs. Vet Clin Pathol 34: 115-123

Campbell TW, Ellis CK (2007) Avian and exotic hematology and cytology. Blackwell Publishing, Ames, IO

Chen CT, Liu KW, Young SJ (1999) Preliminary report on Taiwan's whale shark fishery. In: Fowler SL, Reid T, Dipper FA (eds) Elasmobranch biodiversity, conservation and management. IUCN, Gland, p 162-167

Colman JG (1997) A review of the biology and ecology of the whale shark. J Fish Biol 51:1219-1234

- De Boeck G, Hattink J, Franklin NM, Bucking CP, Wood S, Walsh PJ, Wood CM (2007) Copper toxicity in the spiny dogfish (Squalus acanthias): urea loss contributes to the osmoregulatory disturbance. Aquat Toxicol 84:133-141

Editorial responsibility: Hans Heinrich Janssen,

Oldendorf/Luhe, Germany
Graham RT, Roberts CM (2007) Assessing the size, growth rate and structure of a seasonal population of whale sharks (Rhincodon typus Smith 1828) using conventional tagging and photo identification. Fish Res 84:71-80

Graham RT, Roberts CM, Smart JCR (2006) Diving behaviour of whale sharks in relation to a predictable food pulse. J R Soc Interface 3:109-116

Gross WB, Seigel HS (1983) Evaluation of the heterophil/ lymphocyte ratio as a measure of stress in chickens. Avian Dis 27:972-979

> Hartman FA, Lessler MA (1964) Erythrocyte measurements in fishes, amphibia and reptiles. Biol Bull 126:83-88

> Martin RA (2007) A review of behavioural ecology of whale sharks (Rhincodon typus). Fish Res 84:10-16

Metcalf VJ, Gemmell NJ (2005) Fatty acid transport in cartilaginous fish: absence of albumin and possible utilization of lipoprotein. Fish Physiol Biochem 31:55-64

Old JM, Huveneers C (2006) Morphology of the blood cells from three species of wobbegong sharks (Orectolobus species) on the east coast of New South Wales. Zoo Biol 25: 73-82

Pica A, Lodato A, Grimaldi MC, Della Corte F (1990) Morphology, origin and functions of the thrombocytes of elasmobranchs. Arch Ital Anat Embriol 95:187-207

> Rasmussen LEL, Murru FL (1992) Long-term studies of serum concentrations of reproductively associated steroid hormones in individual captive carcharhinids. Aust J Mar Freshw Res 43:273-281

> Rowat D, Meekan MG, Engelhardt U, Pardigon B, Vely M (2007) Aggregations of juvenile whale sharks (Rhincodon typus) in the Gulf of Tadjoura, Djibouti. Environ Biol Fishes 80:465-472

Seibel BA, Walsh PJ (2002) Trimethylamine oxide accumulation in marine animals: relationship to acylglycerol storage. J Exp Biol 205:297-306

Snyder GK, Sheafor BA (1999) Red blood cells: centerpiece in the evolution of the vertebrate circulatory system. Am Zool 39:89-98

> Stevens JD (2007) Whale shark (Rhincodon typus) biology and ecology: a review of the primary literature. Fish Res 84:4-9

Stokes EE, Firkin BG (1971) Studies of the peripheral blood of the Pork Jackson shark (Heterodontus portusjacksoni) with particular reference to the thrombocyte. Br J Haematol 20:427-435

Walsh CJ, Luer CA (2004) Elasmobranch hematology: identification of cell types and practical applications. In: Smith M, Warmolts D, Thoney D, Hueter R (eds) The elasmobranch husbandry manual: captive care of sharks, rays and their relatives. Ohio Biological Survey, Columbus, $\mathrm{OH}, \mathrm{p} 307-324$

Submitted: May 11, 2009; Accepted: March 30, 2010

Proofs received from author(s): April 29, 2010 